
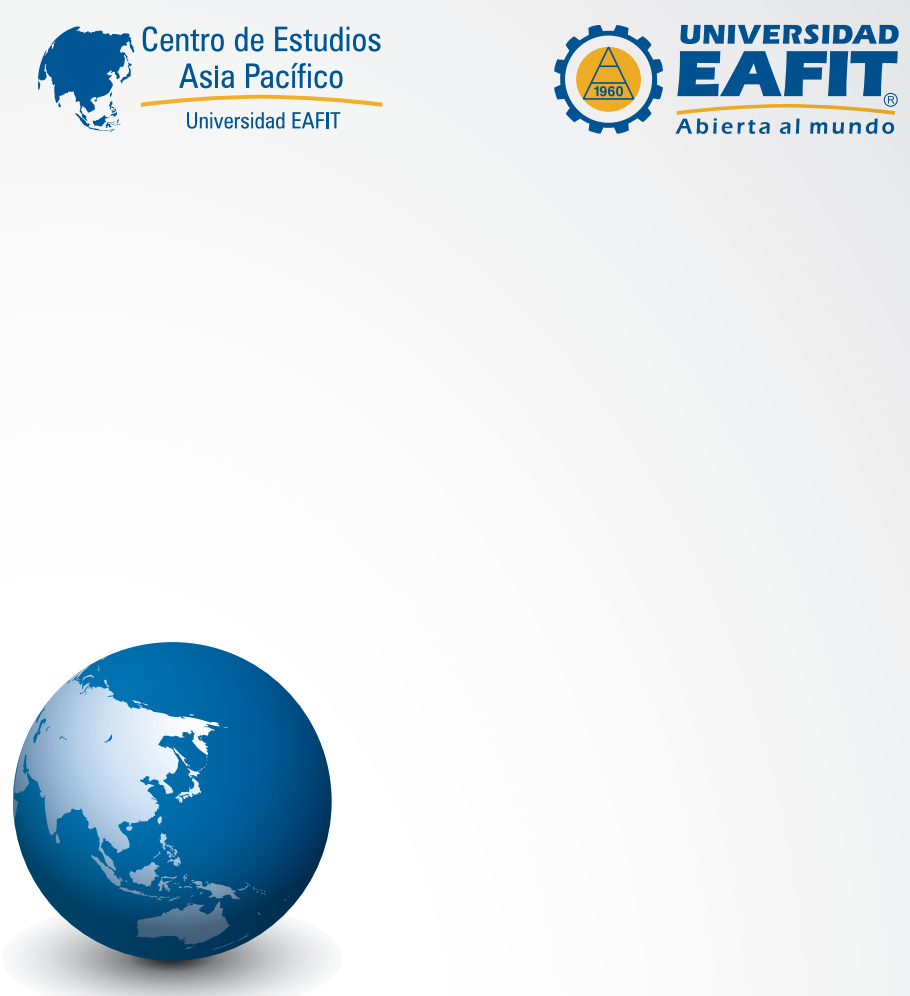

\title{
REVISTA DIGITAL
}
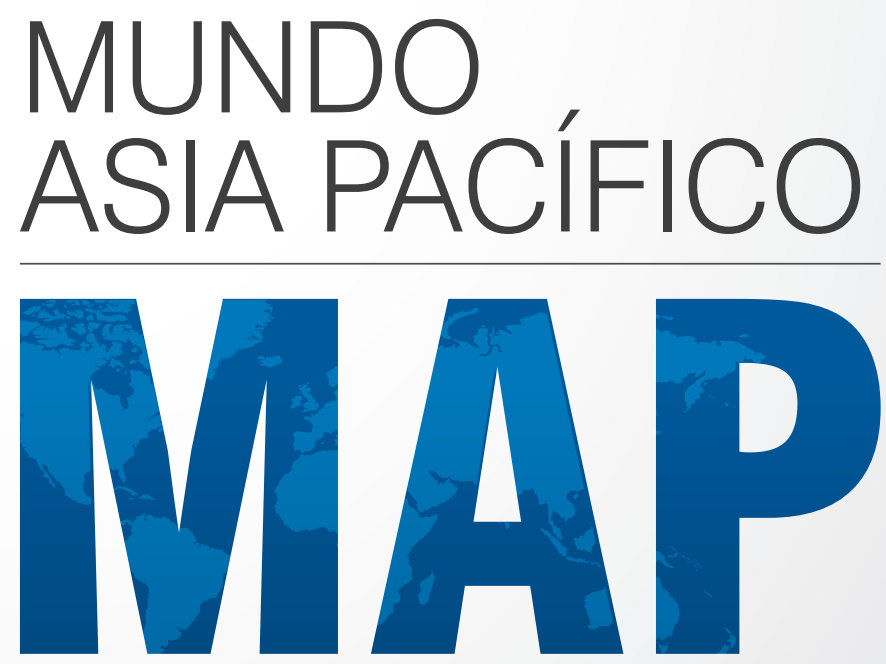

CENTRO DE ESTUDIOS ASIA PACÍFICO UNIVERSIDAD EAFIT

Vol.3 | Número 4 | Enero - Junio 2014 | ISSN 2344-8172 


\section{RELACIONES INTERNACIONALES}
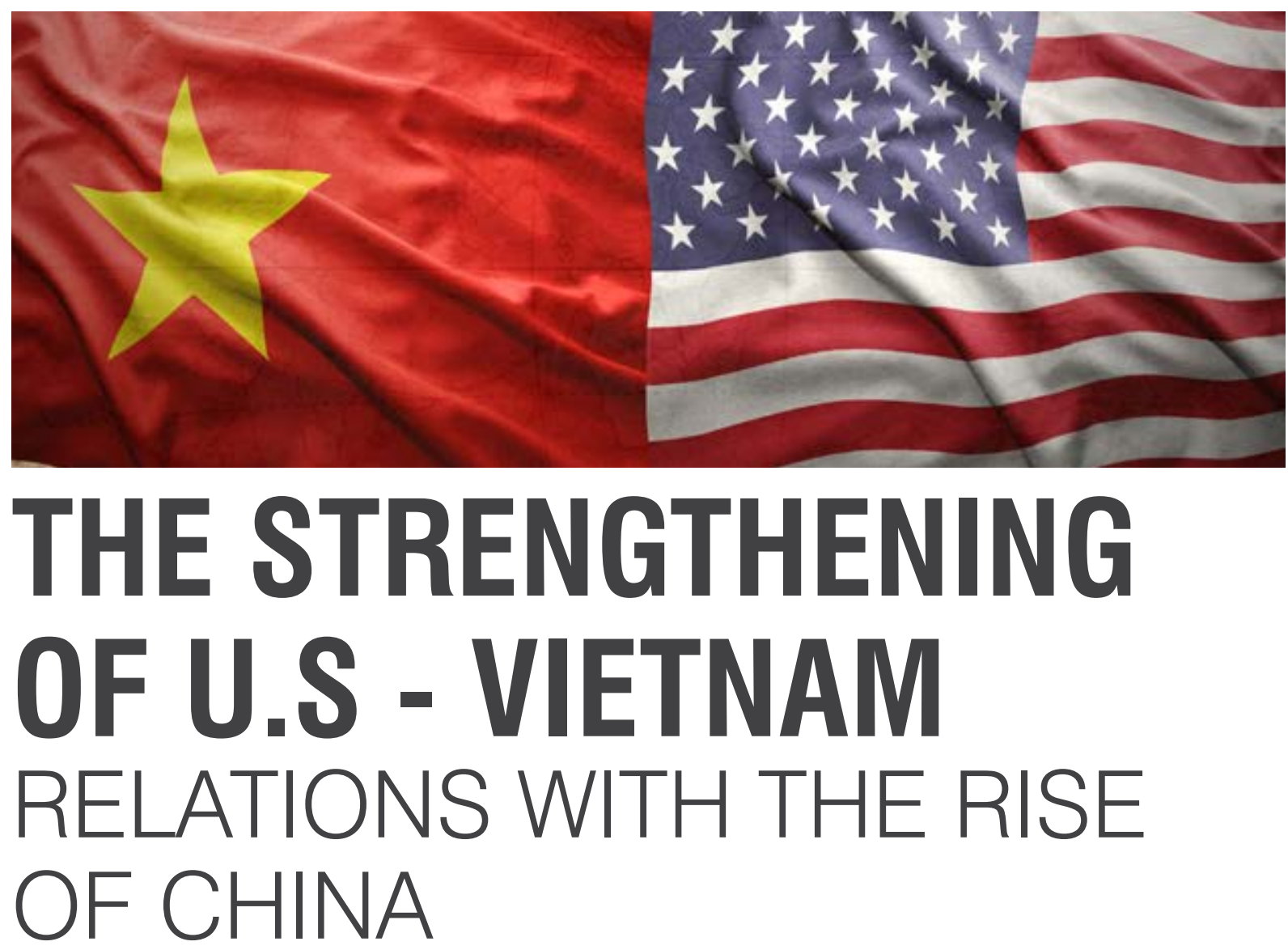

$>>$

\section{Laura Osorio Gómez \\ Universidad EAFIT \\ E-mail: lauraosoriogomez@gmail.com}

\section{Cristina Soler Velez}

Universidad EAFIT

E-mail: cristinasolervelez@gmail.com

\section{Abstract}

Since the defeat of the United States on the Vietnam War, the relations between the two countries were minimal until 1995, when diplomatic relations were re-established. The rise of China as an important actor in East Asia has captured the attention of Obama's administration, which considers the AsiaPacific region as a geostrategic priority for the United States.

This situation has led to a policy shift, and the U.S has led efforts toward the strengthening of the relations with Vietnam, as a strategy to counterbalance the hegemony of China in the region and to maintain its influence in the East of Asia Obama's administration has encouraged Vietnam to be a full partner in the ongoing Trans-Pacific Partnership negotiation (TPP), has given higher priority to cleaning the sites contaminated by Agent Orange, has helped Vietnam in the dispute of waters and islands in the South China Sea, and both countries have signed a new agreement on civilian nuclear cooperation and non-proliferation cooperation (Manyin, 2013).

\section{Resumen}

Desde la derrota de Estados Unidos en la Guerra de Vietnam, las relaciones entre ambos países fueron mínimas hasta 1945, cuando se restablecieron las relaciones diplomáticas. El asenso de China como un importante actor en el Asia Pacífico ha captado la atención de la administración Obama, que consi- 
dera esta región como una prioridad geoestratégica para los Estados Unidos. Esta situación ha generado un cambio en la política. Estados Unidos ha realizado esfuerzos para fortalecer los lazos con Vietnam como estrategia para hacerle contrapeso a la hegemonía en la región, y así mantener su influencia en el Asia Pacífico.

La administración de Obama ha incentivado a Vietnam a convertirse en un aliado en el marco de las negociaciones del Acuerdo Estratégico Transpacífico de Asociación Económica. Así mismo, le ha dado mayor prioridad a la limpieza del territorio contaminado por el Agente Naranja, y ha apoyado a Vietnam en la disputa territorial por las islas en el Mar del Sur de China. Además, ambos países han firmado un acuerdo en cooperación nuclear y de no-proliferación de armas nucleares (Manyin, 2013).

\section{Introduction}

The Vietnam War (1954-1975) was a prolonged struggle between the communist government of North Vietnam and its allies in the South. These allies were known as the Viet Cong, and were against the government of South Vietnam and its principal ally, the United States.

The conflict took place in the context of the Cold War, an ideological war between the two dominant blocks, capitalism and communism. North Vietnam wanted to unite all the territory under a single communism regime while the South aimed to preserve a Vietnam more closely aligned with the Western model. The United States intervened, as it already had intervened in other wars with its containment strategy, in order to fight the expansion of communism.

\section{Retrospective analysis}

The military involvement of the U.S began in 1961 during John F. Kennedy's administration when 17.000 military advisers were sent to support South Vietnam. The conflict was intensified as the number of American troops escalated from 4.000 soldiers in 1962 to 500.000 in 1967, under Johnson's government. This period was characterized by massive bombings and the use of Agent Orange. ${ }^{1}$

In 1975 North Vietnam defeated the South and unified the country under its regime. The disengagement of the U.S in the War during Nixon administration (1969-1974) and the strong assistance of the Soviet Union made the North strong enough to win the war. As a consequence U.S imposed an embargo over Vietnam that lasted until 1994.

From the North Vietnam's victory until 1995, the relations between both countries were minimal. Nevertheless, there were government-to-government negotiations between Vietnam and the U.S under presidency of Jimmy Carter (1977-1978), Ronald Reagan (1989) and George H.W. Bush (1991) until fruition in 1995 under President Bill Clinton (Brown, 2010). These previous government actions prepared the ground for the normalization of the relations under Clinton's administration.

Subsequent to the normalization of diplomatic relations, President Bill Clinton announced the appointment of the first post-war ambassador to Vietnam.

\footnotetext{
1 Agent Orange: Mixture of herbicides that U.S. military forces sprayed in Vietnam from 1962 to 1971 during the Vietnam War for the dual purpose of defoliating forest areas that might conceal Viet Cong and North Vietnamese forces and destroying crops that might feed the enemy (Encyclopedia Britannica, 2013). In the long- term the chemicals used ends affecting people's health and is the cause of mutation syndromes. These cruel tactics marked the history of both countries.
} 
Moreover, Clinton was the first president after Nixon to visit Vietnam. During the visit, Vietnamese leaders pressed the U.S. for compensation for Agent Orange victims, for assistance locating the remains of Vietnam's soldiers still missing, and for an increase in the United States' bilateral economic assistance program (Manyin, 2013).

It was only until the term of President George W. Bush that the economic relations were re-established. The first step toward the normalization was the ratification of the Bilateral Trade Agreement (BTA) in 2001, and then the decisive step was the accession of Vietnam to the World Trade Organization (WTO) in 2007.

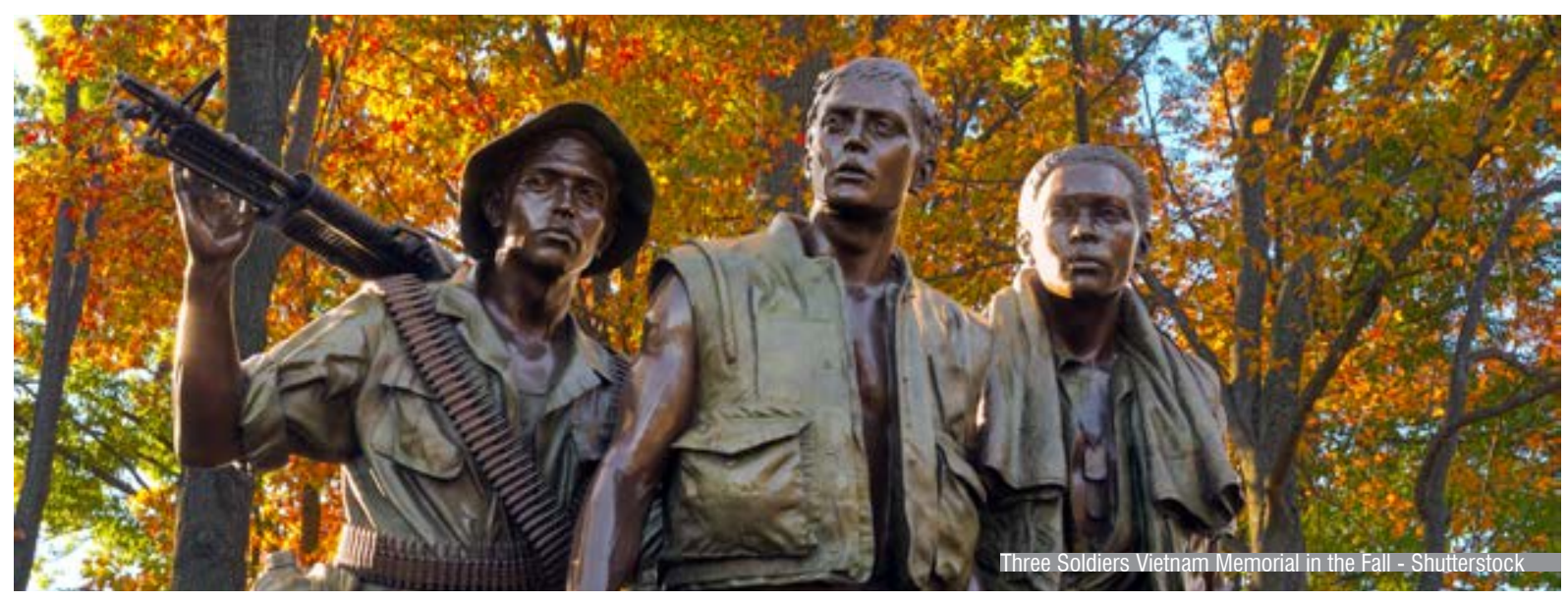

\section{The Rise of China}

According to Christopher Layne, before the Great Recession in 2008, most American security studies scholars believed that unipolarity and American hegemony would be enduring features of international politics far into the future. However in the Great Recession's aftermath, it is apparent that much has changed since 2008.

The recession brought about some changes in the international system: the shift of global wealth and power from West to East, exemplified by the China's rapid rise to status of great power, and the emergence of doubts about the robustness of the U.S economy (Layne, 2013). The flaws in the American system accompanied with China's prosperity resulted in the end of the unipolar world and U.S hegemony, and the birth of multipolarity.

According to Layne (2013) \& Sutter et al. (2013) the American engagement in Asia-Pacific is not a new issue. In fact the U.S has always considered this regions as a relevant geopolitical interest. The involvement in Asia began since World War II, and was deepened throughout the Cold War era and maintained during the post Cold War era.

Regarding, the case of Vietnam, the Clinton and Bush administrations made important efforts in normalizing the relations with the socialist country. However the 9/11 attacks captured the attention of U.S foreign policy, which meant Asia held a less important position on its agenda.

The rise of China has highly modified the strategy of the United States toward Asia-Pacific, re-capturing its attention. China has been established as an important priority for the U.S since it is no longer the world's hegemonic power. The U.S perceives China as a threat to the influence it exercises over the region.

As stated in the essay The Rise of China and Its Implications by Professor Fred Engst (2011), the United States is concerned about China's power due to the fact that it is the largest economy not under the control of the U.S. Other major 
powers such as Germany and Japan, which have U.S military bases cannot be considered truly independent of the U.S. Moreover, China's incredible appetite for worldwide resources due to the rapid development of its industries will inevitably bring it into conflict with the U.S.

Supporting the author above mentioned, Nicholas D. Kristoff (1993) emphasizes that China's fast growing military budget, the possession of nuclear weapons and the fact that it is involved in border disputes with most of its neighbors in the South China Sea, reaffirms the situation of China becoming a threat for the United States. Furthermore, since its accession to the WTO in 2007, China has turned into a more active and influential actor within the international arena.

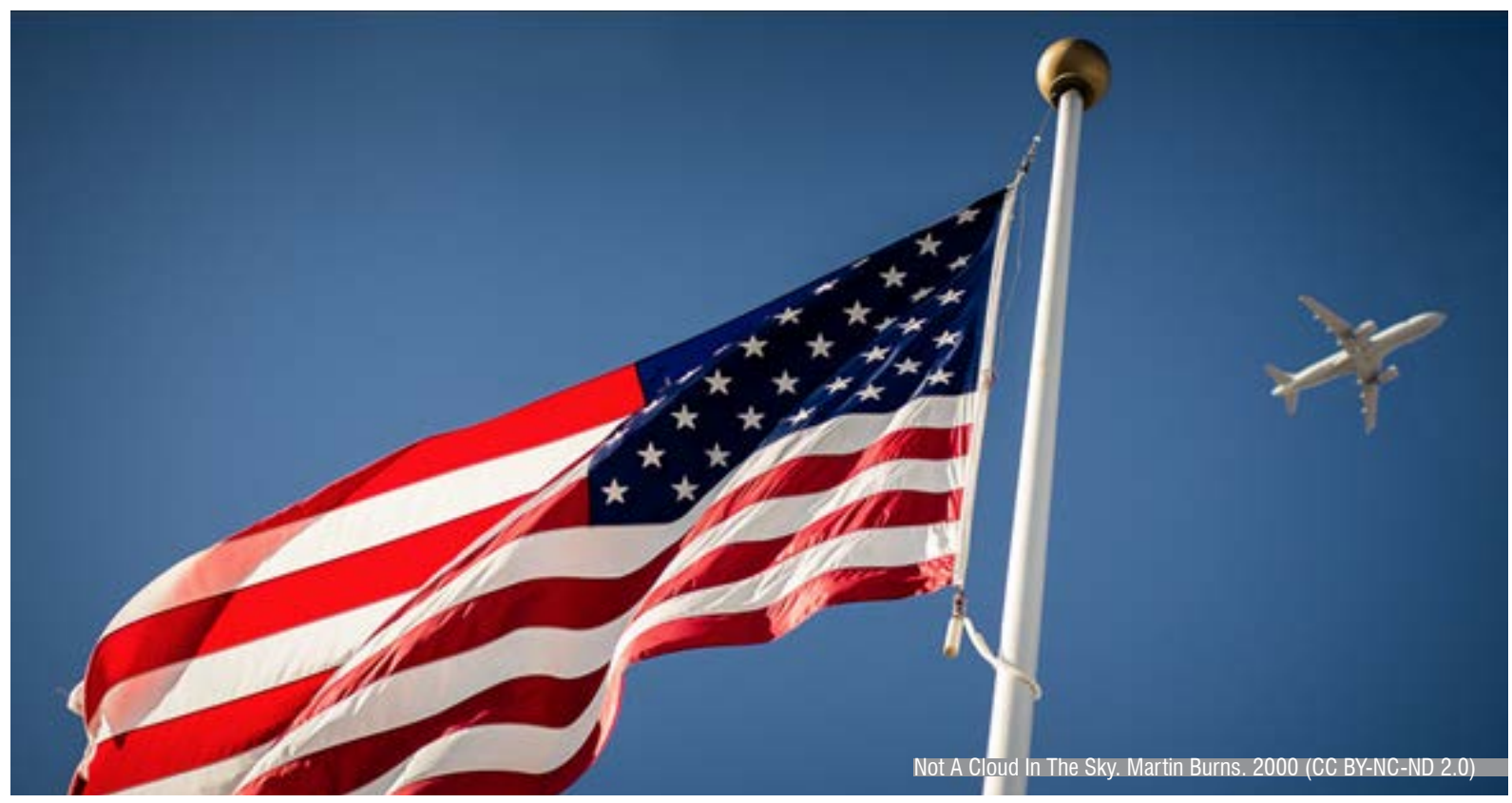

Obama's Administration

Starting in 2010, Obama's administration started focusing on Vietnam as a strategic partner, as a means to counterbalance China's influence in the Asia Pacific. Afterwards the then Secretary of State Hillary Clinton, in her speech during the East Asia Summit materialized the strategy adopted by the government towards the Asian region: "The Obama Administration is prepared to take the U.S.-Vietnam relationship to the next level (...) We see this relationship not only as important on its own merits, but as part of a strategy aimed at enhancing American engagement in the Asia-Pacific and in particular Southeast Asia" (Manyin, 2013).

The peak of U.S - Vietnam relations was in 2010 with the visits of the Secretary of State Hillary Clinton and the Secretary of Defense Robert Gates. In July, Clinton participated in the ASEAN Regional Forum (ARF) meeting. It was the first time that the U.S publicly expressed its concern about Chinese assertiveness in the South China Sea. Then, in October the Fifth East Asia Summit was held. With the representation of Hillary Clinton, the U.S decided to participate in this event for the first time. That same month, Gates took part in the First ASEAN+6+2 Defense Ministers' Meeting, where the central topic was the U.S concern about China's actions in the South China Sea. An important event to highlight is that in 2010, the U.S and Vietnam started having military-to-military discussions in the Defense Policy Dialogue. 
Later that year, in an initiative of the Obama Administration to rebalance the Asia-Pacific, the United States encouraged Vietnam to become a full partner on the Trans-pacific Economic Partnership (TPP). The TPP is a multilateral high-standard free trade agreement that involves 12 countries from both sides of the Pacific Basin and aims to go beyond of that established under the framework of the WTO. At the moment the TPP negotiations have had 20 secret rounds and it is expected that by the end of this year the negotiations will be concluded.

On July 25, 2013 President Truong Tan Sang visited Obama in the White House. The meeting's objective was to affirm the mutual commitment to opening a new phase in the relation based on mutual respect and common interests. President Truong Tan Sang's visit came at an important time for both nations, reflecting a shared desire to build a forward-looking relationship between the two countries (The White House, 2013).

The outcome of this meeting was the signature of the U.S-Vietnam Comprehensive Partnership that is intended to intensify the contributions on peace, stability, cooperation and prosperity between both countries. It will also create mechanisms for cooperation in areas including political and diplomatic relations, trade and economic ties, science and technology, education and training, environment and health, war legacy issues, defense and security, protection and promotion of human rights, and culture, sports, and tourism. One of the most important advances of the Comprehensive Partnership was in the War Legacy issue. Both Heads of State agreed on a higher commitment; on the one hand was U.S promoting greater contributions to clean up the Agent Orange legacy, whilst Vietnam sought to build trust in contributing with the $\mathrm{POW} / \mathrm{MIA}^{2}$ issue.

Another issue where progress was made was in the promotion and protection of human rights. Both presidents declared that they would encourage open dialogue to enhance mutual understanding and narrow the differences on human rights. Vietnam informed about the efforts made in promoting human rights, mainly protecting the rights of religious believers which are highly violated in the communist country.

The rise of China has influenced U.S foreign policy. President Obama passed from having just one Middle East focus based on the war on terror, to adopt a wider-range of strategies, in which Asia was included. Starting in 2010, the Obama administration started focusing in Vietnam as a strategic partner as a means to counterbalance China's influence in the Asia-Pacific by strengthening the diplomatic, economic and military ties.

\section{Interests of the United States and Vietnam to strengthen the bilateral relation}

According to Manyin (2013), the supporters of U.S improving relations with Vietnam argue that the main interests of approaching that country has to do with the considerable trade and investment flows, the large Vietnamese community living in the U.S, the moral duty to improve the negative legacies left by the war, promote democracy and protect human rights, counterbalance China's influence in the region, achieve freedom of navigation in the South China Sea, and to enhance U.S influence in South East Asia.

The author also states, that Vietnam is trying to upgrade its relations with the United States due to their desire to access U.S markets and because the U.S represents one of the major sources of foreign direct investment, and at the

2 POW-MIA issue (Prisoners of War/ Missing in Action): This term is usually used to refer to people that disappeared during the war. 
same time to counter China's power in the region and to maintain territorial integrity in the South China Sea. Vietnam also perceives U.S as a positive economic influence, since they want to become an industrialized country by 2020 . Despite the mutual interests that both parties have and the efforts made towards rapprochement, the U.S and Vietnam face some underlying problems of differences that do not allow them to have a relation based on real trust. On the one hand the United States supports democracy, and on the other, Vietnam supports a socialist regime with a single party.

Furthermore, the United States is concerned about the violation of human rights in Vietnam. The U.S criticizes the lack of press freedom because of the government's monopoly in this field. Also, the ethnic minorities are discriminated and sometimes not even recognized by the government. Religious freedom is one of the U.S main concerns because the Vietnamese Communist Party (VCP) monitors the activities of the religious organizations. In terms of the workers rights issue, Vietnam has made efforts to improve the poor labor conditions, but workers are not free to form their own independent unions because they should belong to that labor unions approved by the VCP. Regarding human trafficking, Vietnam is a source and destination for people trafficked for forced labor and sexual exploitation (Manyin, 2013). Although these issues have ameliorated the U.S is still requesting better conditions in order to go further in the relation.

Vietnam's main concern is that the ultimate goal of the U.S in this country is to end the VCP monopoly in power. Also, the economic ties with China are important enough to be concerned of upsetting Beijing because of the strengthening of the relations with Washington. "Sino-Vietnamese relations are Vietnam's most important bilateral relationship and Vietnamese leaders must tiptoe carefully along the tightrope between Washington and Beijing, such that improved relations with one capital not be perceived as a threat to the other" (Manyin, 2013, p.1).

\section{Conclusions}

The Rise of China is not the only cause for the rapprochement between both countries. There are other important topics in which they need mutual cooperation. They have considerable trade and investment flows and there is a large Vietnamese community living in the U.S. Moreover, the legacy of the Vietnam War is also an important issue for both countries; on the one hand Vietnam needs U.S support in order to compensate the victims and clean up the soils that are still contaminated with Agent Orange. On the other, the United States has the moral duty to improve the negative legacies left by the war. It is important to highlight, that the rapprochement between the United States and Vietnam was a process instead of a single moment. The official normalization of the relations began in 1994 and has been becoming stronger since that moment, thanks to the efforts made by the different administrations. However, the United States and Vietnam have substantive differences, which hinder the functioning of the rapprochement process. For instance, Vietnam has a socialist regime leaded by a single party, while the U.S promote democracy. Furthermore, the United States is concerned about the violation of human rights in Vietnam.

Despite the differences, the rise of China represents a central aspect where the United States and Vietnam converge. The fact that China is rising and becoming unduly assertive in South East Asia strengthens the possibility for strategic cooperation between both countries. 


\section{References}

- Brown, F. Z., \& Tuan, H. A. (2010). Rapprochement between Vietnam and the United States/ Rapprochement between Vietnam and the United States: A response. Contemporary Southeast Asia, 32(3), 317-349.

- Engst, F. (2011). The Rise of China and its Implications. University of International Business and Economics, Beijing.

- Grinter, L. E. (2006). China, the United States, and mainland Southeast Asia: Opportunism and the limits of power. Contemporary Southeast Asia, 28(3), 447-465

- Kristof, N. D. (1993). The Rise of China. Retrieved April 26, 2014 from Rise of China-Foreign Affairs: http://www.foreignaffairs.com/articles/49405/nicholas-d-kristof/the-rise-of-china

- Manyin, M. E. (2013). U.S.- Vietnam Relations in 2013: Current Issues and Implications for U.S. Policy. Retrieved January 4, 2014, from Congressional Research Service: https://www.fas.org/sgp/crs/row/ R40208.pdf

- $\quad$ Nguyen, H. H. (2013, July 25). The Diplomat. Retrieved February 4, 2014, from US- Vietnam Ties: Time for a Rethink?: http://thediplomat.com/2013/07/us-vietnam-ties-time-for-a-rethink/

- $\quad$ Office of the Press Secretary. (2013, July 25). The White House. Retrieved February 4, 2014, from Joint Statement by President Barack Obama of the United States of America and President Truong Tan Sang of the Socialist Republic of Vietnam

- $\quad$ Sutter, R. G., Brown, M., Adamson, T. J., Mochizuki, M. M., \& Ollapally, D. (August de 2013). Balancing Acts: The U.S. Rebalance and Asia-Pacific Stability. Sigur Center for Asian Studies Journal, 1-43.

- Wndsor, R. E. (1968). Vietnam and United States Policy in Asia. Royal Institute of International Affairs, 44 (2), 202-213. 